\title{
ОСМИСЛЕНІСТЬ ЖИТТЯ ЛІТНІХ ЖИТЕЛІВ СІЛЬСЬКОЇ МІСЦЕВОСТІ
}

\section{Коваленко Олена Григорівна}

Доктор психологічних наук, дочент, дочент кафедри психологї, Полтавський наџіональний педагогічний університет імені В.Г.ККороленка, м. Полтава (Украӥна)

\begin{abstract}
Анотація. Стаття присвячена проблемі осмисленості життя літніх селян. Охарактеризовано соціальні і вікові особливості літніх селян. Розглянуто наукові підходи до проблеми осмисленості життя літніх осіб. Обгрунтовано напрямки вивчення психологічних особливостей літніх селян. Емпірично підтверджено, щзо літні селяни мають недостатню здатність осмислювати власне життя і розуміти його зміст. У більшості з них виникають проблеми з розумінням сутності та спрямованості власного життя, які здебільшого зумовлені змінами, щзо в ньому відбуваються. Літні селяни часто незадоволені свойм сучасним життям і не вірять у власну здатність впливати на нього, живуть минулим. Доведено, щзо життя літніх жителів сіл є менш осмисленим, ніж у літніх жителів міст. Встановлено, щуо у своєму житті літні селяни найбільше прагнуть змінити його спосіб, умови.
\end{abstract}

Ключові слова: осмисленість життя, смисл життя, ичілі в житті, процес життя, результативність життя, локус контролю - Я, локус контролю - життя.

\section{Постановка проблеми у загальному} вигляді. Відповідно до даних Держкомстату України, третина (32\%) населення нашої держави проживає у сільській місцевості (2007). При чому, четверта частина (24.1\%) сільського населення складають особи віком більше 60 років, у той час, як серед міського населення таких лише п'ята частина (18,5\%) [6]. Тобто, сільське населення складає значиму частину демографічного складу України і досить знач- на частина сільського населення - літнього i старечого віку. На соціальному, економічному, політичному становищі, на психологічних особливостях саме такого літнього сільського населення найбільше відображаються динамічні процеси, які відбуваються в сучасному суспільстві.

Літні люди - важлива соціальна спільнота, чиє дитинство припало на відновлення країни після Другої світової війни, моло- 
дість - на час застою, зрілість - на розпад СРСР і економічне зубожіння, пізня зрілість на час війни із сусідньою державою. Життя людей цього віку в селі має низку особливостей, зокрема, це зайнятість важкою фізичною працею, необхідність обробітку землі (городу і саду), догляду за тваринами; сезонність фізичної роботи; ізольованість проживання; ускладнений доступ до медичної допомоги і побутових послуг. Порівняно з молодшими жителями села, літні люди не схильні до виїзду на заробітки по країні чи за кордон; вони мають стабільний, хоча і невеликий фінансовий прибуток (отримують пенсію). У старості людина може ставати селянином, переїжджаючи 3 міст. Також у цьому віці змінюється професійний статус людини, актуалізуються різноманітні проблеми зі здоров'ям. Враховуючи такі особливості важливим є вдосконалення життєдіяльності літніх селян. У цьому необхідним $€$ розуміння ними змістовності свого життя, його смислу.

\section{Аналіз останніх досліджень і публіка-} цій. Проблемами пошуку смислу життя, у тому числі в літньому віці займалися такі філософи та науковці, як К. О. АбульхановаСлавська, A. Adler, I. Д. Бех, Б. М. Смалетдінов, О. В. Краснова, Д. О. Леонтьєв, О. М. Леонтьєв, С. Д. Максименко, В. А. Роменець, М. М. Рубінштейн, М. Л. Смульсон, V. Frankl, B. Е. Чудновський, C. G. Jung та інші. Психологічним особливостям селян, у тому числі літнього віку увагу приділяли
Л. С. Акопян, R. Birrer-Hardwick, M. R. Crowthe, I. Г. Губерладзе, К. Є. Демида, A. S. Dibner, P. Constanca, F. Oswald, Р. М. Шамионов та інші.

Жителі села - особлива соціальнодемографічна група, яка має властиві їй вікові, соціально-психологічні особливості і соціальні цінності, котрі зумовлені рівнем соціальноекономічного і культурного розвитку конкретного соціуму. Селяни є більш відкритими у спілкуванні, між ними менше соціальних і культурних відмінностей, ніж між жителями міст; їхні взаємини є досить тісними й активними, можуть бути різними за емоційним полюсом. На такі особливості впливає невелика за розміром територія і незначна щільність населення. Порівняно із містянами, селяни також більше залежать від чинників зовнішнього соціального середовища $[1 ; 2]$.

Р. М. Шаміонов досліджуючи особливості психологічного благополуччя містян i селян виявив, що рівень такого благополуччя в них суттєво не відрізняється хоча селянам складніше протидіяти соціальному тискові, вони більше орієнтуються на думку інших осіб при ухваленні важливих рішень, вони $є$ менш відкритими новому досвіду й рідше мають відчуття саморозвитку. Головними стратегіями адаптації селян, що визначають їхнє благополуччя базуються на горизонтальному індивідуалізмі і колективізмі, у той час як у містян - на вертикальному індивідуалізмі [9]. Зв’язок особливостей соціальної підтримки та 
психологічного благополуччя літніх селян досліджувався J. Н. Patrick [10]. Не було виявлено відмінностей рівнів у процесі сприйняття емоційної підтримки літніми жінками і чоловіками в селах, хоча вони мають певні особливості у джерелах такої підтримки. Так, психологічне благополуччя літніх чоловіків визначається більшою задоволеністю сімейною підтримкою, що пов'язано з меншим негативним впливом та більш високим позитивним впливом. Для психологічного благополуччя літніх жінок важливою є емоційна підтримка друзів, хоча їхнє задоволення емоційною підтримкою від сім'ї також пов'язано з більш низьким рівнем негативного впливу.

Психологічне благополуччя літніх селян визначається пошуком й оновленням ними смислу свого життя. Смисл життя є досить складною морально-світоглядною категорією, яка неоднозначно аналізується різними вченими. Найчастіше пов'язується із діяльністю, когінтивно-мотиваційними компонентами. Його розглядають як мету (ціль) життя, усвідомлений і узагальнений принцип життя, життєву задачу, потребу особистості, вчинок, спрямованість життя. Смисл життя вважають значимою цінністю людини, наголошують на аналізові життя у пошуку його смислу. Втрата смислу життя призводить до певних психічних проблем, хвороб. Конкретизують зміст даного феномену у смисложиттєвих орієнтаціях. Смисл життя розглядають як важливу детермінанту особистісного розвитку на будь- якому віковому етапі. Психологічним особливостям пошуку смислу життя у пізньому віці $\begin{array}{ll}\text { увагу приділяли } & \text { В. Е. Чудновський, }\end{array}$

Б. М. Смалетдінов, М. Л. Смульсон, О. В. Краснова [4].

Смисл життя людини Б. М. Смалетдінов аналізує як когнітивномотиваційний компонент іiі особистості і свідомості, світогляду, який виявляє заради чого необхідна діяльність людини, що визначається соціальними нормами цього світогляду. Кожен віковий період має локальний смисл життя, а інтегральний смисл життя узагальнює всі смисложиттєві переживання, які відбулися. Пошук смислу життя є функцією самосвідомості, що полягає в інтеграції та координації мотиваційної сфери. Б. М. Смалетдінов виявив особливості смислу життя людини на різних вікових етапах. Він вважає, що смисл життя людини у похилому віці і старості полягає у ретроспективній оцінці свого життя, його змісту; це може супроводжуватися, з однієї сторони, відчуттям невідповідності життя ідеалові, неможливості апробувати інші стилі життя, з іншої сторони - відчуттям здійснення планів і цілей, прийняття минулого (відчай або цілісність 3 точки зору Е. Еріксона). 3 такої боротьби виникає «мудрість» як якість Его, що відображає спробу знайти цінність і смисл життя перед близькою смертю. Особи цього віку зорієнтовані на пізнання і культуру, продовження професійного життя, накопичення, турботу про онуків, відпочинок і радість 
від життя у теперішній час, релігію, лікування своїх хвороб (цитує Б. М. Смалетдінов Г. С. Сухобську) [3].

В. Е. Чудновський смисл життя людини визначає як ідею, яка містить мету життя людини, і яка була «привласнена» нею і стала для неї найвищою цінністю. Він порівнює особливості ставлення до смислу життя осіб різного віку: у період дорослішання зростаючі життєві сили налаштовують на пошук перспективи і життєвого смислу, старість сприяє розвиткові песимізму, зосереджує увагу на обмеженості, смертності буття людини [8]. Тобто у молодості людина зорієнтована на майбутнє, а у старості - на усвідомлення обмеженості свого життя.

Смисл життя у старості, як зазначає М. Л. Смульсон, $є$ стрижнем, ціннісноорієнтувальною основою ментальної моделі світу людини (іï особистого досвіду, який пройшов інтелектуальну обробку. містить зміст та рівень розуміння людиною себе, інших та довкілля) [7]. Екзистенціальна проблема смислу у старості, на відмінну від попередніх періодів вирішується «тут і тепер». У цьому віці важливим $є$ збереження власної картини світу (утримання структури сенсу життя, що розпадається), її перетин з картиною світу оточуючих осіб. Останнє є критерієм істини для старіючої людини. Виявити особливості такого перетину вона може, вступаючи у безпосередню взаємодію з оточенням, міжособистісне спілкування. М. Л. Смульсон також ви- окремлює умови позитивного життєвого смислу у старості. По-перше, гармонія між цілями, цінностями людини та ролями, потребами соціальної структури. По-друге, відчуття наближення до досягнення своїх цілей із швидкістю, що людину задовольняє.

Проблемами, пов'язаними із пошуком людиною смислу життя у пізньому віці займається така нова дисципліна, про яку згадує О. В. Краснова, - наративна геронтологія. Вона вивчає як старіюча людина шукає чи надає значення своєму життю через його історію. Головна ідея наративної геронтології полягає у тому, що розвиток ідентичності вважають процесом, що триває все життя. Людина шукає смисл свого життя, аналізуючи та перевіряючи його, переписуючи своє минуле, вона доповнює нові значимі лінії історії до свого життя [5].

Не зважаючи на представленість досить широкого спектру досліджень смислу життя, науковцями недостатньо уваги приділялося психологічним особливостям пошуку смислу життя, його осмисленості особами віку пізньої дорослості з різних місць проживання. Тому метою даної роботи було виявити особливості осмисленості життя літніх селян.

\section{Контингент і матеріали дослідження.} У діагностичному дослідженні взяли участь 184 літні особи віком від 55 до 78 років. Середній вік досліджуваних - 66,53 років. Серед них у селах проживають 128 осіб, а у містах 56 осіб. Серед досліджуваних жителів сільсь- 
кої місцевості - 31 чоловік і 97 жінок; 95 осіб мають початкову, або середню, або неповну середню, або середню спеціальну освіту, 33 особи - вищу або незакінчену вищу освіту; зараз працюють 27 осіб, а 101 - не працює.

Для діагностики використаний тест смисложиттєвих орієнтацій (СЖО), розроблений Д. О. Леонтьєвим. Додатково збирали інформацію про певні соціальні особливості літніх жителів сіл за допомогою інтерв'ю.

Результати дослідження. Установили середні значення та розподіл рівнів (у \%), згідно з результатами Д. О. Леонтьєва як за зага- локус контролю - життя (ЛК-Ж) у досліджених осіб різної статі (Табл. 1).

Аналіз отриманих емпіричних даних дозволяє стверджувати, що літні селяни мають недостатню здатність осмислювати власне життя і розуміти його зміст: середнє значення за загальним показником осмисленості життя у чоловіків $(92,42)$, і у жінок $(93,60)$ цього віку відображає нижчий від середнього рівень. У більшості літніх селян (чоловіки $61 \%$, жінки - 56\%) виникають проблеми з розумінням сутності та спрямованості власного життя, які здебільшого зумовлені змінами, що

Розподіл літніх селян за рівнями смисложиттєвих орієнтацій

Таблиця 1.

\begin{tabular}{|l|c|c|c|c|c|}
\hline \multirow{2}{*}{ Показник ОЖ } & \multicolumn{5}{|c|}{ Чоловіки (n=31) } \\
\cline { 2 - 6 } & $\begin{array}{c}\text { середнс } \\
\text { значення }\end{array}$ & низький, \% & $\begin{array}{c}\text { нижчий від } \\
\text { середн., \% }\end{array}$ & $\begin{array}{c}\text { вищий від се- } \\
\text { редн., \% }\end{array}$ & високий, \% \\
\hline ЦЖ & 29,52 & 45 & 16 & 23 & 16 \\
\hline ПЖ & 28,13 & 48 & 16 & 13 & 23 \\
\hline РЖ & 22,68 & 39 & 35 & 10 & 16 \\
\hline ЛК-Я & 18,81 & 35 & 23 & 29 & 13 \\
\hline ЛК-Ж & 26,52 & 33 & 35 & 29 & 3 \\
\hline ОЖ & 92,42 & 19 & 42 & 23 & 16 \\
\hline & \multicolumn{5}{|c|}{ Жінки (n=97) } \\
\hline ЦЖ & 30,70 & 16 & 25 & 26 & 33 \\
\hline ПЖ & 26,88 & 29 & 31 & 21 & 19 \\
\hline РЖ & 23,08 & 14 & 40 & 26 & 20 \\
\hline ЛК-Я & 19,05 & 17 & 29 & 28 & 26 \\
\hline ЛК-Ж & 27,23 & 28 & 26 & 33 & 13 \\
\hline ОЖ & 93,60 & 27 & 29 & 23 & 21 \\
\hline
\end{tabular}

льним показником осмисленості життя (ОЖ), так і за показниками його чинників (цілі в житті (ЦЖ), процес життя (ПЖ), результативність життя (РЖ), локус контролю - Я (ЛК-Я), в ньому відбуваються. Літні селяни часто незадоволені своїм сучасним життям і не вірять у власну здатність впливати на нього, живуть минулим. Найбільше проблем із цим має четверта частина досліджених жінок (27\%) і п'я- 
та частина чоловіків (19\%) із сільської місцевості. Серед літніх селян менше тих, хто, маючи цілі на майбутнє, не будує безвідповідальних планів, порівняно задоволений своїм минулим і теперішнім життям, вірить у власну здатність контролювати окремі події власного життя й розуміє його залежність від різноманітних сторонніх чинників. Серед чоловіків таких $39 \%$, а серед жінок $-44 \%$.

Обгрунтовуючи середні значення за чинниками осмисленості життя літніх селян, варто вказати, що за показником «цілі в житті» він у чоловіків є нижчим від середнього $(29,52)$, а в жінок - вищим від середнього $(30,70)$. Більшість літніх чоловіків і частина жінок не завжди здатні бачити цілі в майбутньому, котрі надають їхньому життю осмисленість і спрямованість. Найбільші проблеми у цьому - у майже половини досліджених літніх чоловіків (45\%), які не помічають перспектив у своєму подальшому житті, живуть минулим. Натомість, такі перспективи краще відзначають жінки: третина 3 них (33\%) є цілеспрямованими. Більшість досліджених жінок (59\%) не схильні жити тільки минулим або сьогоденням і не будують безвідповідальних планів на майбутнє.

Літні селяни вважають своє життя недостатньо цікавим, емоційно насиченим і наповненим смислом: середнє значення за чинником «процес життя» і в чоловіків $(28,13)$, і в жінок $(26,88)$ є нижчим від середнього. Більше половини досліджених осіб (чоловіки - 64\%, жінки - 60\%) мають низькі і нижчі від середнього значення за показником наповненості смислом процесу життя. Серед чоловіків виявлено майже половину (48\%) таких, які найбільше незадоволені своїм сучасним життям. Тих, кого таке життя загалом влаштовує серед літніх людей меншість (чоловіки - 36\%, жінки $-40 \%)$.

Переважна більшість чоловіків (74\%) і більше половини жінок (54\%) не повною мірою задоволені результатами свого прожитого життя. Середнє значення по вибірці за цим чинником («результативність життя») у них $€$ нижчим від середнього (чоловіки - 22,68, жінки - 23,08). Лише четверту частину досліджених чоловіків (26\%) і трохи менше половини жінок (46\%) порівняно влаштовують результати попереднього життя.

За чинником «локус контролю - Я» літні селяни мають середній рівень, але в чоловіків він є нижчим від середнього (середнє значення - 18,81), а в жінок - вищим від середнього (середнє значення - 19,05). Вони сприймають себе як досить сильних особистостей, в яких $є$ певна свобода вибору для побудови свого життя відповідно до власних цілей та уявлень про його смисл. Але в жінок порівняно 3 чоловіками трохи більше віри у можливість такої свободи. Серед чоловіків третина (35\%) тих, хто не вірить у свої сили контролювати події власного життя.

За чинником «локус контролю - життя» літні селяни мають нижчий від середнього 
рівень (середнє значення: чоловіки - 26,52, жінки - 27,23). Вони усвідомлюють певну обмеженість можливості контролювати своє життя й розуміють вплив різних чинників на прийняття рішень та їхнє здійснення. Більш фаталістичними є третина досліджених чоловіків (33\%) і четверта частина жінок (28\%). Серед літніх чоловіків 3 сільської місцевості майже не виявлено тих, хто впевнений, що здатен вільно приймати рішення і втілювати їх у життя (3\%).

Перевірка достовірності відмінності між величинами як загальних показників осмисленості життя, так і показників їі чинників у літніх селян різної статі за допомогою tкритерію Стьюдента (відмінність достовірна показником $(\mathrm{t}=1,20)$; натомість відмінним за показниками цілей у житті $(\mathrm{t}=2,08)$ і процесу життя $(\mathrm{t}=2,12)$. Це свідчить про те, що загалом рівень осмисленості життя в літніх селян різної статі суттєво не відрізняється, хоча жінки сприймають його емоційно насиченішим і мають більше планів на майбутнє, ніж чоловіки.

Виявили відмінності за загальним показником осмисленості життя і за показниками його чинників у досліджених літніх жителів міст і сіл. Можемо стверджувати, що літні селяни мають нижчі рівні за всіма показниками осмисленості життя, ніж містяни (Табл. 2).

Перевірка достовірності відмінності між величинами як загальних показників осмисленості життя, так і показників її чинниТаблиця 2.

\section{Осмисленість життя літніх жителів сіл і міст}

\begin{tabular}{|l|c|c|c|}
\hline \multirow{2}{*}{\multicolumn{1}{|c|}{ Показник ОЖ }} & \multicolumn{2}{|c|}{ Середнс значення } & \multirow{2}{*}{ т-критерій } \\
\cline { 2 - 3 } & Жителі сіл $(\mathrm{n}=128)$ & Жителі міст $(\mathrm{n}=56)$ & \\
\hline Цілі в житті & 30,41 & 33,00 & 2,198 \\
\hline Процес життя & 27,18 & 31,02 & 3,049 \\
\hline Результативність життя & 22,98 & 25,98 & 3,267 \\
\hline Локус контролю-Я & 18,99 & 21,57 & 2,881 \\
\hline Локус контролю-життя & 27,05 & 29,50 & 2,122 \\
\hline Осмисленість життя & 93,31 & 102,98 & 2,826 \\
\hline
\end{tabular}

на рівні значущості $\alpha=0,05$, tкр=1,98) дала змогу стверджувати, що рівень осмисленості життя в досліджених літніх селян різної статі $є$ однаковим за показниками результативності життя $(\mathrm{t}=0,79)$, локусу контролю - Я $(\mathrm{t}=0,48)$, локусу контролю - життя $(\mathrm{t}=1,30)$ і загальним ків в літніх селян і містян за допомогою tкритерію Стьюдента (відмінність достовірна на рівні значущості $\alpha=0,05$, ткр $=1,98)$ дала змогу стверджувати, що рівень осмисленості життя в них є різним, життя літніх жителів сіл $є$ менш осмисленим, ніж у літніх жителів міст. 
Літні селяни мають більше проблем, ніж літні містяни в усвідомленні певних цілей свого життя, що надають йому осмисленості, спрямованості і часової перспективи; вони рідше уважають його емоційно насиченим; більш негативно ставляться до свого минулого; недостатньо розуміють власну обмежену здатність контролювати окремі події теперішнього життя й будувати його відповідно до своїх цілей та уявлень про його смисл.

Для уточнення особливостей осмисленості життя ми також опитали літніх селян про те, щоб вони змінили у своєму житті, аби була можливість. На це питання не відповіли $31 \%$ досліджених (40 осіб). Не знають, що змінили б у власному житті, 4,5\% (6 осіб). Не скажуть про те, що змінили б у власному житті, 2,5\% (3 особи). Нічого б не змінили у власному житті 12,5\% (16 осіб). Змістовні відповіді отримані від 49\% досліджуваних (63 особи).

Змістовні відповіді щодо бажаних змін у власному житті можна класифікувати за кількома напрямами: 1) спосіб життя (стиль); 2) робота; 3) місце проживання; 4) фінансове становище; 5) рідні; 6) самотність; 7) вік; 8) житлові умови; 9) інше.

Розглянемо ці відповіді більш детальHо.

Спосіб життя не задовольняє 17\% досліджуваних (22 особи). Вони прагнуть можливості «змінити спосіб життя»; «завести курочок»; «відпочивати на природі - у місті / у гоpax / біля моря»; «поїхати в санаторій / за кор- дон; «мандрувати»; «організувати персональну виставку вишиванок»; «збільшити бюджет часу на творчу діяльність»; «мати свій автомобіль»; «стати депутатом»; «побудувати завод для переробки сміття» тощо.

Робота цікавить 6\% досліджуваних (8 осіб). Вони хотіли б знову працювати: «змінила б професію»; «працювала б як колись» тощо.

Фінансове становище. Змін у ньому стосуються відповіді 5\% досліджуваних (7 осіб). Люди хочуть мати нормальне матеріальне забезпечення - більшу пенсію або можливість заробити гроші, щоб вистачило коштів на лікування («вилікував би дружину», Л. Т., 74 р.) і на допомогу дітям (онукам).

Рідні, їхнє життя - об’єкт змін, яких прагнуть 5\% досліджуваних (7 осіб): «щоб син був живий» (прагне С. І., 66 р.); «щоб рідні жили ближче»; «щоб у дітей усе було добре»; щоб була можливість «більше часу приділяти родині / жити дружно з сім'єю».

Місце проживання змінили б 4,5\% досліджуваних (6 осіб). Це засвідчують такі відповіді: «переїхала б туди, де жила до пенсії» (Л. С., 57 р.); «повернулася б на батьківщину» (С. Т., 65 р.); «поїхала б жити до дітей» (П. П., 70 р.); тощо.

Вік - предмет думок 4,5\% досліджуваних (6 осіб). Вони замислюються над незворотністю змін - «повернути б молодість»; «стати б молодшою»; «виглядати б молодшою» i т. ін. 
Житлові умови змінили б 4\% досліджуваних (5 осіб). Вони хотіли б «мати більший будинок»; «купити внукам окреме житло»; «придбати будинок» тощо.

Самотність турбує 4\% досліджуваних (4 осіб). Вони б хотіли її позбутися: «знайшла б чоловіка з грошима» (зазначила К. І., 59 р.); «женився би знову» (О. П., 68 р.) і т. ін.

Інше зазначили 4,5\% досліджуваних (6 ністю. У пізньому віці людині важливо проаналізувати й оцінити своє життя загалом, зберегти смисл життя у поточний момент. Здійснення цього має свої особливості у такої соціально-демографічної групи, як літні селяни. У процесі дослідження виявлено, що багато літніх селян мають низький і нижчий від середнього рівні осмисленості життя, що свідчить про те, що вони незадоволені своїм сучасним

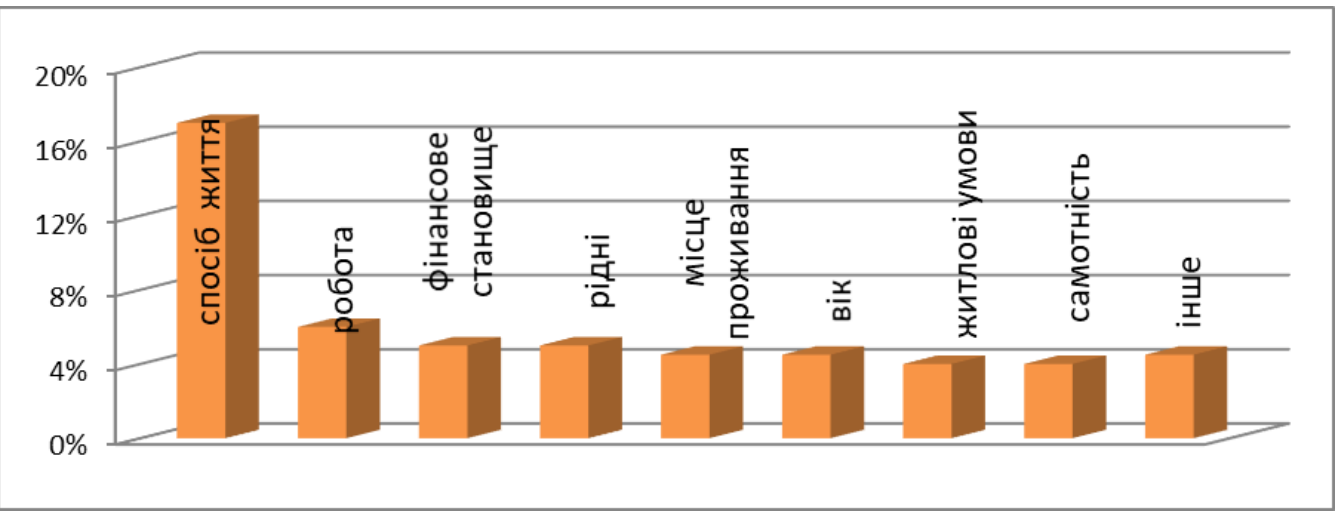

Рис. 1. Напрямки бажаних змін у житті літніх осіб

осіб): «щоб людям жилося краще»; «повернути б час назад»; «отримати б вищу освіту»; «провела б телефон».

Напрямки бажаних змін у житті літніх осіб представлено на Рис. 1.

Отже, більшість змін у житті літніх селян стосується способу, стилю життя. Це пов’язане із їхньою невпевненістю ним повноцінно керувати, визначати події свого сучасного й майбутнього життя.

Висновки. Смисл життя людини є метою життя, усвідомленим і узагальненим його принципом, життєвою задачею, значимою цін- життям, не впевнені у власній здатності впливати та змінювати його, хоча вони хочуть це зробити. У майбутньому літні селяни особливих перспектив не помічають, і вважають, що туди не варто загадувати. Натомість минуле життя вони також не сприймають як достатньо продуктивне і осмислене. Їм не зовсім цікаво жити. У сільській місцевості літні жінки краще, ніж чоловіки розуміють сутність та спрямованість власного життя. Причини недостатньої здатності літніх осіб до осмисленості життя можливі в організації життя літніх людей у сільській місцевості, у їхньому фінансо- 
вому становищі, у взаєминах 3 оточуючими людьми, зокрема літні селяни вказують на брак близького довірливого спілкування, вони нечасто бачать поряд тих осіб, симпатія до яких є взаємною. Отже, загалом можна стверджувати, що життя літніх селян $є$ менш осмисленим, ніж у літніх містян.

\section{Перспективи подальших досліджень} можливі у виявленні психологічних особливостей літніх жителів сіл і порівнянні цих особливостей 3 психологічними особливостями літніх жителів міст.

\section{Перелік використаних джерел:}

1. Гаврилова Н. В. Психологические особенности жителей села: анализ и практика исследования [Електронний ресурс] / Н. В. Гаврилова, Ж. Б. Есмурзаева // Концепт. - 2012. - № 10, октябрь. С. 1-8. // Режим доступу до джерела : https:// cyberleninka.ru/article/v/psihologicheskie-osobennostizhiteley-sela-analiz-i-praktika-issledovaniya.

2. Губерладзе I. Г. Порівняльний аналіз соціальнопсихологічних особливостей сільської та міської спільнот / І. Г. Губерладзе // Психологічні науки : проблеми i здобутки : зб. / Київ. міжнар. ун-т, Ін-т соц. та політичної психології НАПН України. - К. : КиМУ. - 2011. Вип. 2. - С. 41-55.

3. Коваленко О.Г. Міжособистісне спілкування осіб похилого віку: психологічні аспекти : монографія / О. Г. Коваленко. - К. : Інститут обдарованої дитини, 2015. - $456 \mathrm{c}$.

4. Краснова О.В. Идентичность в позднем возрасте: нарративный подход / О.В.Краснова // Современная социальная психология : теоретические подходы и прикладные исследования. - 2012. - № 4. - С. 46-53.

5. Населення України. Соціально-демографічні пробле- ми українського села : монографія. - К. : Ін-т демографії та соціальних досліджень НАН України, 2007. $468 \mathrm{c}$.

6. Смульсон М. Л. Готовність до саморозвитку як психологічна умова успішності особистості / М. Л. Смульсон // Успішність особистості: потенціал та обмеження : тези доповідей Міжнар. наук.практич. конференції (К., 18.03.2010 р.) / за ред. : М. Л. Смульсон, Л. М. Зінченко. - К. : Вид-во НПУ ім. М. П. Драгоманова, 2010. - С. 228-230.

7. Чудновский В. Э. Становление личности и проблема смысла жизни: избранные труды / В. Э. Чудновский. М. : Изд-во Московского психолого-социального института; Воронеж : Изд-во НПО «МОДЭК», 2006. $768 \mathrm{c.}$

8. Шамионов Р. М. Базовые убеждения и культурные установки как предикторы эмоционального и психологического благополучия горожан и сельчан / Р. М. Шамионов // Социальная психология и общество. - 2015. - Т. 6, № 4. - С. 109-122.

9. PatrickJ. H. Gender, Emotional Support, and WellBeing Among Rural Elderly [Електронний pecypc] / J. H. Patrick, L. E. Cottrell, K. A. Barnes // Sex Roles. - July 2001. - Volume 45, issue 1-2. - p. 1529. // Режим доступу до джерела : https:// link.springer.com/article/10.1023/A:1013056116857.

\section{References (Transliteration):}

1. Gavrilova N. V. Psihologicheskie osobennosti zhitelej sela : analiz i praktika issledovaniya [Elektronnij resurs] / N. V. Gavrilova, ZH. B. Esmurzaeva // Koncept. 2012. - № 10, oktyabr'. - S. 1-8. // Rezhym dostupu do dzherela : https://cyberleninka.ru/article/v/psihologicheskie -osobennosti-zhiteley-sela-analiz-i-praktika-issledovaniya.

2. Huberladze I. H. Porivnialnyi analiz sotsialnopsykholohichnykh osoblyvostei silskoi ta miskoi spilnot / I. H. Huberladze // Psykholohichni nauky : problemy i zdobutky : zb. / Kyiv. mizhnar. un-t, In-t sots. ta politychnoi psykholohii NAPN Ukrainy. - K. : KyMU. - 
2011. - Vyp. 2. - S. 41-55.

3. Kovalenko O. H. Mizhosobystisne spilkuvannia osib pokhyloho viku : psykholohichni aspekty monohrafiia / O. H. Kovalenko. - K. : Instytut obdarovanoi dytyny, 2015. $-456 \mathrm{~s}$.

4. Krasnova $O . V$. Identichnost' v pozdnem vozraste: narrativnyj podhod / O. V. Krasnova // Sovremennaya social'naya psihologiya: teoreticheskie podhody i prikladnye issledovaniya. - 2012. - № 4. - S. 46-53.

5. Naselennia Ukrainy. Sotsialno-demohrafichni problemy ukrainskoho sela : monohrafiia. - K. : In-t demohrafii ta sotsialnykh doslidzhen NAN Ukrainy, 2007. - 468 s.

6. Smulson M. L. Hotovnist do samorozvytku yak psykholohichna umova uspishnosti osobystosti / M. L. Smulson // Uspishnist osobystosti: potentsial ta obmezhennia : tezy dopovidei Mizhnar. nauk.-praktych. konferentsii (K., 18.03.2010 r.) / za red. M. L. Smulson, L. M. Zinchenko. - K. : Vyd-vo NPU im. M. P. Drahomanova, 2010. - S. 228-230.

7. Chudnovskij V. Eh. Stanovlenie lichnosti i problema smysla zhizni: izbrannye trudy / V. Eh. Chudnovskij. - M. : Izd-vo Moskovskogo psihologo-social'nogo instituta ; Voronezh : Izd-vo NPO «MODEHK», 2006. - 768 s.

8. Shamionov R. M. Bazovye ubezhdeniya i kul'turnye ustanovki kak prediktory ehmocional'nogo i psihologicheskogo blagopoluchiya gorozhan i sel'chan / R. M. Shamionov // Social'naya psihologiya i obshchestvo. - 2015. - T. 6, № 4. - S. 109-122.

9. PatrickJ.H. Gender, Emotional Support, and WellBeing Among Rural Elderly [Електронний pecypc] / J. H. Patrick, L. E. Cottrell, K. A. Barnes // Sex Roles. - July 2001. - Volume 45, issue 1-2. - p. 1529. // Режим доступу до джерела : https:// link.springer.com/article/10.1023/A:1013056116857.

\section{Kovalenko Olena}

Doctor of Psychology, Associate Professor, Associate Professor of the Department of Psychology, Poltava V. G. Korolenko National Pedagogical University, Poltava (Ukraine)

\section{MEANINGFULNESS OF LIFE OF ELDERLY RESIDENTS OF RURAL AREAS}

\section{ABSTRACT}

The article is devoted to the problem of comprehension of the life of the elderly residents of rural areas (villagers). Residents of the rural area is a special socio-demographic group, which has its own age, socio-psychological features and social values, which are determined by the level of socio-economic and cultural development of a specific society. We characterized the social and age characteristics of older villagers. The scientific approaches to the problem of the meaning of life, its meaningfulness in old age are considered. Scientists emphasize that it is important for an older person to analyze and evaluate his life, and to preserve the meaning of life at the moment.

The total number of participants took part in the study was 184 elderly people. The age of the participants was from 55 to 78 years. The average age of the subjects was 66.53 years. We used the test of meaningfulness orientation by Dmitriy Leontiev. Also we collected the information about some social features of elderly villagers through interviews.

It is empirically confirmed that the elderly villagers lack the ability to comprehend their own lives and understand its meaning. Most of them 
have problems understanding the nature and orientation of their lives, which are largely due to changes in it. Old villagers are often dissatisfied with their today's way of life and do not believe in their own ability to influence it; they live in their past. They are not always able to notice goals in the future, which make their lives meaningful and purposeful. Old villagers consider their life to be insufficiently interesting, emotionally rich and full of meaning. Many of them are not fully satisfied with the results of their past life. A minority of those who are relatively satisfied with the results of previous life have been identified. They perceive themselves as very strong personalities, who have a freedom of choice to build their lives in accordance with their own purposes and ideas about its meaning. Women have more faith in the possibility of such freedom compared to men. Old villagers are aware of the limited ability to control their lives and understand the influence of various factors on decision making and their implementation.

Using the Student's t-test it was confirmed that, firstly the level of meaningfulness of life in the elderly men and women who live in rural areas is not significantly different, although women perceive it emotionally more intense and have more plans for the future than men; secondly the lives of elderly villagers are less meaningful than the elderly inhabitants of cities.

It has been established that the elderly villagers are most keen to change their way of life, living conditions. They also want to work, im- prove their financial position, solve problems with their relatives, etc.

Key words: meaningfulness of life, sense of life, goals in life, process of life, effectiveness of life, locus of control - I, locus of control - life.

\section{Коваленко Елена Григорьевна}

Доктор психологических наук, дочент, доцент кафедры психологии, Полтавский национальный педагогический университет имени В. Г. Короленко, г. Полтава (Украина)

\section{ОСМЫСЛЕННОСТЬ ЖИЗНИ ПОЖИЛЫХ ЖИТЕЛЕЙ СЕЛЬСКОЙ МЕСТНОСТИ}

\section{Аннотация. Статья посвящена про-} блеме осмысленности жизни пожилых селян. Жители села - особая социальнодемографическая группа, которая имеет присущие ей возрастные, социальнопсихологические особенности и социальные ценности, обусловленные уровнем социальноэкономического и культурного развития конкретного социума. Охарактеризованы социальные и возрастные особенности пожилых жителей села. Рассмотрены научные подходы к проблеме смысла жизни, его осмысленности в старости. Ученые отмечают, что в этом возрасте для человека важно проанализировать и оценить свою жизнь в целом, сохранить смысл жизни в текущий момент.

В исследовании приняли участие 184 пожилых человека в возрасте от 55 до 78 лет. Средний возраст испытуемых - 66,53 лет. Для диагностики использован тест смысложизнен- 
ных ориентаций (СЖО), разработанный Д. А. Леонтьевым. Дополнительно собирали информацию об определенных социальных особенностях пожилых жителей сел с помощью интервью.

Эмпирически подтверждено, что пожилые жители села имеют недостаточную способность осмысливать собственную жизнь и понимать ее содержание. У большинства из них возникают проблемы с пониманием сущности и направленности своей жизни, обусловленные в основном изменениями, которые в ней происходят. Пожилые жители села часто недовольны своей современной жизнью и не верят в собственную способность влиять на нее, живут прошлым. Они не всегда способны видеть цели в будущем, которые придают их жизни осмысленность и направленность. Пожилые жители села считают свою жизнь недостаточно интересной, эмоционально насыщенной и наполненной смыслом. Многие из них не полностью удовлетворены результатами своей прожитой жизни. Выявлено меньшинство тех, кого сравнительно устраивают результаты предыдущей жизни. Они воспринимают себя как достаточно сильных личностей, имеющих определенную свободу выбора для построения своей жизни в соответствии со своими целями и представлениями о ее смысле. Но у женщин по сравнению с мужчинами больше веры в возможность такой свободы. Пожилые жители села осознают определенную ограниченность возможности контролировать свою жизнь и понимают влияние различных факторов на принятие решений и их осуществление.

$\mathrm{C}$ помощью t-критерия Стьюдента подтверждено, что, во-первых, уровень осмысленности жизни у пожилых жителей села разного пола существенно не отличается, хотя женщины воспринимают еe эмоционально насыщеннее и имеют больше планов на будущее, чем мужчины; во-вторых, жизнь пожилых жителей сел менее осмыслена, чем у пожилых жителей городов.

Установлено, что в своей жизни пожилые жители села больше всего стремятся изменить ее образ, условия жизни, также хотят работать, улучшить финансовое положение, решить проблемы с родными людьми и тому подобное.

Ключевые слова: осмысленность жизни, смысл жизни, цели в жизни, процесс жизни, результативность жизни, локус контроля Я, локус контроля - жизнь. 